data for the study were taken from the open source data.egov.kz, which provides fresh information on the incidence rate in 3 regions of the Republic of Kazakhstan. The methodology is based on the use of methods of descriptive statistics, graphical data analysis, building models on the SAS platform and can be applied for a more in-depth analysis of the incidence rate for various population groups, as well as for their description in the regions of Kazakhstan.

Key words: data analysis, SAS platform, open source, incidence rate, model.

Сведения об авторах:

Алтаева Зарина Алтынбекқызы, магистрант первого курса специальности «Бизнесаналитика» кафедры «Информационные системы» Международного университета информационных технологий.

Аманжолова Жібек Русланқызы, магистрант первого курса специальности «Бизнесаналитика» кафедры «Информационные системы» Международного университета информационных технологий.

Молдагулова Айман Николаевна, кандидат физико-математических наук, и.о. профессора, Международный университет информационных технологий.

Алимжанова Лаура Муратовна, к.т.н., ассоциированный профессор, Международный университет информационных технологий.

Куатбаева Акмарал Алихановна, Ph.D. по информатике, ассистент-профессора кафедры «Информационные системы», Международный университет информационных технологий.

УДК 530.1, 681.3.06

\author{
Malikaidar S., Toikenova U. \\ International Information Technology University \\ Almaty, Kazakhstan \\ Scientific superviser: Sarsembayev A.
}

\title{
SIGN LANGUAGE RECOGNITION USING DEEP LEARNING METHODS
}

Abstract. Sign language gesture recognition employs various problems, such as variabilities in handshapes, movements, signers' facial expressions and etc. Hence, teaching a machine to recognize the patterns that consider all of the problems mentioned above is a big challenge. The main goal of this work is to develop a set of methods and techniques involving deep learning in order to build a system capable of highly efficient sign language gesture recognition. In this article, we make brief research among the related works and propose our idea on our future work.

Key words: machine learning, training, testing, dataset, sign language, algorithms

\section{Introduction}

There are more than 18 thousand people with hearing impairments living in Kazakhstan. According to the Ministry of labor and social protection of the population of the Republic of Kazakhstan, out of 18.4 thousand people with hearing disabilities, only 28 percent are employed, that is, 5.2 thousand people. Communication barriers cause the main difficulties in the social immersion of deaf people. The main way of communication for deaf people is the sign language. Sign language is a specific language consisting of gestures and their combinations, made by hand positions. There are a lot of problems faced by deaf people. One of the big issues is the ignorance of sign language by many non-deaf people. For example, people with hearing impairments cannot

International Journal of Information and Communication Technologies, Vol.1, Issue 1, March, 2020 
independently obtain documents at public service centers. An automated system will be able to speed up the process of obtaining documents and make life easier for people with disabilities. The system can be used not only in public service centers, but also in places where people communicate with each other.

\section{Related Work}

Sign language recognition (SLE) is a relatively well-known problem. The interest in this field started to appear in the late eighties. Despite that many computer vision methods have been developed by that time, the methods for gesture recognition were far from being effective due to the lack of computational power. Most of the breakthroughs have appeared in the second decade of the XXI century. Researchers have used various ways of recognizing sign language gestures faster and efficiently. Pu et al. [2] propose a deep learning architecture for continuous SLR a 3D-ResNet for feature extraction and an encoder-decoder network for sequence modeling. The main contribution of this work is resolving a problem of temporal segmentation of signs in sign videos that allows continuous SLR recognition and efficient further training. The method has been tested on two large scale continuous sign language recognition benchmarks, i.e., RWTH-PHOENIX-Weather and CSL. The results presented in this paper were showing relatively low WER rates comparing to few other works in the field. Chong and Lee [6] use the machine and deep learning methods as well. In particular, they apply SVM and DNN on the data acquired from Leap Motion Controller (LMC). LMC is a commercial device that can track hand and finger motion with high precision in the 3D Cartesian coordinate system. Despite that, the authors achieved high results of accuracy scores ( $80 \%$ and $93 \%$ respectively), the employment of external devices to our though is the main disadvantage of the proposed method. Guerrero et al. [4] compare LMC with Microsoft Kinect in their work. The authors also consider the implementation of SVM and ANN. However, after some research, the authors come to the conclusion that ANN outperforms the SVM, and LMC returns more accurate gestures tracking than Kinect. Despite that, the authors reach decent results, this may refer only to static signs and not to continuous natural speech. Vo et al. [3] implement similar approaches to the researchers mentioned above. However, this work addresses Vietnamese sign language. The authors present two decent datasets of Vietnamese sign language collected by their group. Moreover, they propose the data augmentation technique.

Table .1 Researches related to sign language recognition

\begin{tabular}{|c|c|c|c|c|c|c|c|c|c|}
\hline № & Year & $\begin{array}{l}\text { Sensor } \\
\text { based }\end{array}$ & $\begin{array}{l}\text { Computer } \\
\text { vision based }\end{array}$ & $\begin{array}{l}\text { Video / } \\
\text { Picture } \\
\text { based } \\
(\mathrm{V} / \mathrm{P})\end{array}$ & $\begin{array}{l}\text { Sequential speech } \\
\text { recognition (i.g. } \\
\text { Hidden Markov } \\
\text { Model) }\end{array}$ & $\begin{array}{l}\text { Hand } \\
\text { tracking }\end{array}$ & Classifier & Sensor type & Accuracy \\
\hline [1] & 2019 & - & + & $\mathrm{P}$ & - & - & $\begin{array}{c}\text { PCANet, } \\
\text { SVM }\end{array}$ & Kinect & $88.7 \%$ \\
\hline [2] & 2018 & - & + & V & + & + & $\begin{array}{l}\text { 3DResNet, } \\
\text { LSTM }\end{array}$ & Camera & $\begin{array}{c}93.9 \%, \\
\text { precision }\end{array}$ \\
\hline [3] & 2019 & - & + & $\mathrm{P}$ & - & - & $\begin{array}{l}\text { SVM, } \\
\text { ANN }\end{array}$ & Camera & $\begin{array}{c}88.5 \% \\
95.83 \%\end{array}$ \\
\hline [4] & 2019 & + & - & - & + & + & $\begin{array}{l}\text { SVM, } \\
\text { ANN }\end{array}$ & $\begin{array}{l}\text { LMC, } \\
\text { Kinect }\end{array}$ & $100 \%$ \\
\hline [5] & 2019 & - & + & V & + & + & CNN, RNN & Camera & $86.1 \%$ \\
\hline [6] & 2018 & + & - & - & - & + & $\begin{array}{l}\text { SVM, } \\
\text { DNN }\end{array}$ & LMC & $93.8 \%$ \\
\hline
\end{tabular}

International Journal of Information and Communication Technologies, Vol.1, Issue 1, March, 2020 
Aly [1] et al. propose a different approach based on a combination of unsupervised PCANet algorithm and linear SVM model. The authors obtain depth data from Microsoft Kinect sensor. The evaluation on a public dataset shows good results, proving the effectiveness of the approach.

We find that the most relevant work to ours is [5] where Shi et al. focus on recognition of fingerspelling sequences in American Sign Language (ASL) videos collected in the wild, mainly from YouTube and Deaf social media. The work dataset mainly based on fingerspelling, recently introduced as Chicago Fingerspelling in the Wild (ChicagoFSWild). The dataset consists of 7304 fingerspelling sequences from online videos. This data set includes a large number of signers (168) and a wide variety of challenging visual conditions. We use it as one of our test stands. The authors propose an end-to-end model based on an iterative attention mechanism, without explicit hand detection or segmentation. The approach dynamically focuses on increasingly high-resolution regions of interest. It outperforms prior work by a large margin.

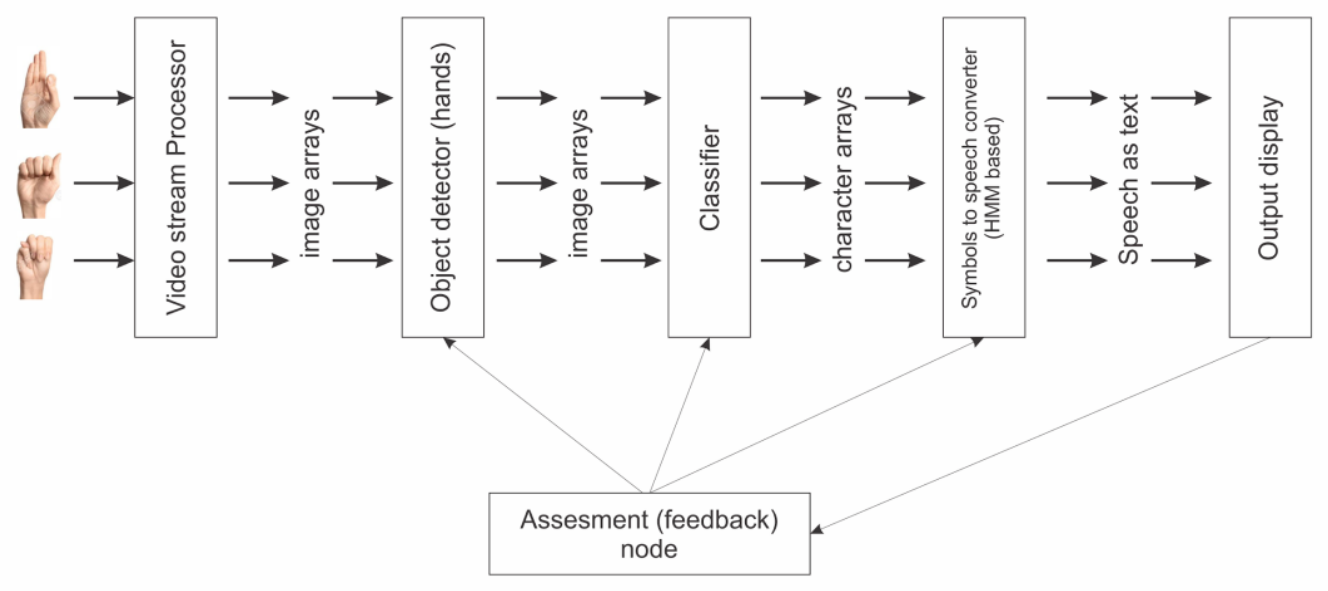

Figure 1. Principal scheme of the system workflow

\section{Conclusion}

Table 1, depicts all the works presented above. We compared several works based on motion capture methods and machine learning for sign language recognition. A few works use the Leap Motion Controller or Microsoft Kinect which recognizes and tracks the main parts of body, like arms or legs, as well as face gestures or voice and the library TensorFlow for training neural networks. The calculation of the coordinates of joints is then performed using the Hidden Markov Model. Some of the researchers use SVM as their main classifier along with DNNs. However, due to that SVM shows higher accuracy on relatively small datasets and lacks efficiency on large ones, implementation of this method should be further discussed.

We target the recognition of all 26 letters of ASL. One of the main difficulties will appear with 2 symbols that are not static. We will need to track the sequence of signs in order to recognize them. There are few works from analyzed above target all of the 26 symbols as well. The principal scheme of the workflow is illustrated on the Figure 1.

\section{REFERENCES}

1. Aly, W., Aly, S. and Almotairi, S., 2019. User-Independent American Sign Language Alphabet Recognition Based on Depth Image and PCANet Features. IEEE Access, 7, pp.123138-123150.

2. $\mathrm{Pu}, \mathrm{J} ., \mathrm{Zhou}, \mathrm{W}$. and $\mathrm{Li}, \mathrm{H} ., 2019$. Iterative alignment network for continuous sign language recognition. In Proceedings of the IEEE Conference on Computer Vision and Pattern Recognition (pp. 4165-4174).

3. Vo, A.H., Pham, V.H. and Nguyen, B.T., 2019. Deep Learning for Vietnamese Sign Language Recognition in Video Sequence. International Journal of Machine Learning and Computing, 9(4).

International Journal of Information and Communication Technologies, Vol.1, Issue 1, March, 2020 
4. Casas, J., Cristobal, J. and Luengo, J., 2019. Motion capture methods and machine learning for sign language recognition (Bachelor's thesis, NTNU).

5. Shi, B., Rio, A.M.D., Keane, J., Brentari, D., Shakhnarovich, G. and Livescu, K., 2019. Fingerspelling recognition in the wild with iterative visual attention. In Proceedings of the IEEE International Conference on Computer Vision (pp. 5400-5409).

6. Chong, T.W. and Lee, B.G., 2018. American sign language recognition using leap motion controller with machine learning approach. Sensors, 18(10), p.3554.

\title{
Маликайдар С., Тойкенова Ұ. \\ Ғылыми жетекші: Сарсембаев А. \\ Ым тілін терендетіп оқыту әдістерімен анықтау
}

Андатпа. Основная цель этой работы - разработать набор методов и техник, включающих глубокое обучение, для создания системы, способоной к высокоэффективному распознаванию жестов на языке жестов. В статье краткое исследование среди связанных работ и предложение нашей идеей для оптимизации.

Кілт сөздер: машинное обучение, обучение, тестирование, датасет, язык жестов, алгоритмы

\section{Маликайдар С., Тойкенова У. Научный руководитель Сарсембаев А.}

Распознавание языка жестов с помощью методов глубокого обучения

Аннотация. Основная цель этой работы - разработать набор методов и техник, включающих глубокое обучение, для создания системы, способоной к высокоэффективному распознаванию жестов на языке жестов. В статье краткое исследование среди связанных работ и предложение нашей идеей для оптимизации.

Ключевые слова: машинное обучение, обучение, тестирование, датасет, язык жестов, алгоритмы

About authors:

Malikaidar Symbat Iliyaskyzy, student, International Information Technology University.

Toikenova Ulzhan Gumyrbekkyzy, student, International Information Technology University. and security».

Sarsembayev Aidos, PhD, Associate Professor of the Department «Computer engineering УДК 004

\author{
Bokan M., Nurbekkyzy A., Bayanbay A. \\ International Information Technology University \\ Almaty, Kazakhstan \\ Scientific supervisers: Satybaldiyeva R.Zh., Kasymova A.B.
}

\section{DEVELOPMENT OF A WEB PORTAL PROVIDING EDUCATIONAL AND SOCIAL SERVICES IN THE FIELD OF ANIMATION}

Abstract. The article presents the basic concept of developing the user interface and a web portal providing educational and social services in the field of animation. The main requirements and characteristics of a web portal are given, and the direct testing procedure is described using the survey and comparative analysis.

Keywords: Animation, 3D Design, effectiveness, tools, profile, multimedia.

International Journal of Information and Communication Technologies, Vol.1, Issue 1, March, 2020 